\title{
Survei Sarana dan Prasarana Pendidikan Jasmani dan Tingkat Kesegaran Jasmani Siswa Kelas VIII SMP PGRI Barembeng Kabupaten Gowa
}

\author{
Survey of Physical Education Facilities and Infrastructure and Physical \\ Fitness Levels of Class VIII Students at SMP PGRI Barembeng, Gowa \\ Regency
}

\author{
M. Sahib Saleh*, Syahru Ramdhani \\ Pendidikan Kepelatihan Olahraga, Universitas Negeri Makasar, Jl. A.P. Pettarani Tidung, 90222, Sulawesi Selatan, \\ Indonesia. \\ e-mail: m.sahib.saleh@unm.ac.id, syahruramdhani@gmail.com
}

\begin{abstract}
Abstrak
Penelitian ini bertujuan (1) Untuk mengetahui keadaan Sarana dan Prasarana Pendidikan Jasmani SMP PGRI Barembeng Kab. Gowa, (2) Untuk mengetahui Tingkat Kesegaran Jasmani Siswa Kelas VIII SMP PGRI Barembeng Kab. Gowa (3), Untuk mengetahui pengaruh sarana dan prasarana terhadap Tingkat Kesegaran Jasmani SMP PGRI Barembeng. Jenis penelitian ini adalah penelitian deskriptif. Populasi penelitian ini adalah semua SMP PGRI Barembeng Kab. Gowa. Sampel penelitian terdiri dari 40 orang siswa putra kelas VIII SMP PGRI Barembeng. Teknik pengumpulan data menggunakan observasi dan tes. Teknik analisis data yang digunakan adalah statistik deskriptif menggunakan fasilitas komputer melalui program SPSS. Berdasarkan analisis data diperoleh hasil: (1) Kondisi sarana dan prasarana yang mendukung pembelajaran penjas SMP PGRI Barembeng dikategorikan ideal, (2) Tingkat kesegaran jasmani kelas VIII SMP PGRI Barembeng dapat dikategorikan sedang, (3) Ada pengaruh sarana dan prasarana terhadap Tingkat Kesegaran Jasmani SMP PGRI Barembeng.
\end{abstract}

Kata Kunci: Sarana dan Prasarana, Tingkat Kesegaran Jasmani

\section{Abstract}

This study aims (1) to determine the state of the Facilities and Infrastructure of Physical Education at SMP PGRI Barembeng, Kab. Gowa, (2) to find out the Physical Fitness Level of Class VIII Students of SMP PGRI Barembeng, Kab. Gowa, (3) to determine the effect of facilities and infrastructure on the Physical Fitness Level of SMP PGRI Barembeng. This type of research is descriptive research. The population of this study were all SMP PGRI Barembeng Kab. Gowa The research sample consisted of 40 male students of class VIII SMP PGRI Barembeng. Data collection techniques using observation and tests. The data analysis technique used is descriptive statistics using computer facilities through the SPSS program. Based on data analysis, the results are obtained; (1) the condition of facilities and infrastructure that supports Physical Education learning at PGRI Barembeng Junior High School is categorized as ide, (2) the level of physical fitness of class VIII SMP PGRI Barembeng can be categorized as moderate, (3) there is an influence of facilities and infrastructure on the Physical Fitness Level of SMP PGRI Barembeng.

Keywords: Facilities and Infrastructure, Physical Fitness

corresponding author: m.sahib.saleh@unm.ac.id

Artikel Info:

Submitted: 04/03/2020

Revised : 25/03/2020

Accepted : 15/04/2020

Published: 20/05/2020

(c) $\underset{\mathrm{Br}}{\mathrm{Br}}$

Journal Coaching Education Sports is licensed under a Creatives Commons Attribution 4.0 International License. 


\section{A. Pendahuluan}

Pendidikan jasmani merupakan bagian integral dari sistem pendidikan secara keseluruhan, yang bertujuan untuk mengembangkan aspek kebugaran jasmani, keterampilan gerak, keterampilan berpikir kritis, stabilitas emosional, keterampilan sosial, penalaran dan tindakan moral melalui aktivitas jasmani yang direncanakan secara sistematis dalam kerangka sistem pendidikan nasional (Herlina \& Suherman, 2020). Pada hakekatnya dalam suatu proses pembelajaran seorang siswa memerlukan adanya dorongan agar kegiatan belajarnya dapat menghasilkan prestasi yang sesuai dengan tujuan yang diharapkan (Pasaribu \& Mashuri, 2019). Untuk dapat meningkatkan prestasi belajar siswa yang maksimal, tentunya perlu diperhatikan berbagai faktor yang dapat membangkitkan siswa untuk belajar lebih giat lagi. Besarnya dorongan atau motivasi setiap siswa dalam belajar juga berbeda-beda, tinggi-rendahnya motivasi siswa tergantung pada faktor intrinsik yaitu siswa itu sendiri, maupun ekstrinsik yaitu bisa dengan adanya sarana dan prasarana yang baik dan lengkap (Lengkana et al., 2017).

Pendidikan jasmani memiliki peran yang sangat penting dalam mengintensifkan penyelenggaraan pendidikan sebagai suatu proses pembinaan manusia yang berlangsung seumur hidup. Pendidikan jasmani memberikan kesempatan pada siswa untuk terlibat langsung dalam aneka pengalaman belajar melalui aktivitas jasmani, bermain, dan berolahraga yang dilakukan secara sistematis, terarah dan terencana (Alif \& Sudirjo, 2019). Pembekalan pengalaman belajar itu diarahkan untuk membina, sekaligus membentuk gaya hidup sehat dan aktif. Melalui pendidikan jasmani diharapkan siswa dapat memperoleh berbagai pengalaman untuk mengungkapkan kesan pribadi yang menyenangkan, kreatif, inovatif, terampil, meningkatkan dan memeliharan kesegaran jasmani serta pemahaman terhadap gerak manusia (Pasaribu \& Daulay, 2018).

Fasilitas dan sarana pembelajaran pendidikan jasmani bagi anak didik berupa tersedianya sarana dan prasarana yang digunakan untuk mencapai tujuan dari proses belajar mengajar dalam pembelajaran pendidikan jasmani olahraga dan kesehatan (Penjas Orkes) (Wijaya, 2017). Pendidikan jasmani memerlukan sarana media pembelajaran, alat dan perlengkapannya. Alat dan media yang sesuai dengan kebutuhan dengan kerakteristik anak didik akan mengembangkan potensi serta keterampilannya secara optimal (Pratama \& Tjahyo, 2018). Untuk mendukung kegiatan http://ejurnal.ubharajaya.ac.id/index.php/JCESPORTS 
proses belajar mengajar pendidikan jasmani dan kesehatan disekolah maka sangat diperlukan sarana dan prasarana. Sarana dan prasarana merupakan komponen atau instruksional yang dipakai oleh guru penjas untuk mempraktekkan semua materi yang diajarkan (Irawan, 2017). Dengan demikian, seorang guru Penjaskes tidak hanya menjelaskan secara teoritis mengenai pembelajaran melainkan menerangkan dengan praktek sesuai teorinya.

\section{SMP PGRI Barembeng Kab.Gowa} sebagai salah satu lembaga pendidikan yang telah memiliki sarana dan prasarana yang mendukung dalam proses belajar mengajar. Sarana dan prasarana yang meliputi gedung yang permanen. Jadi Tingkat kesegaran jasmani SMP PGRI Barembeng Kab.Gowa hanya didapatkan dari berolahraga. Sedangkan kegiatan ekstrakuikuler di luar jam sekolah antara lain seperti PMR, OSIS dan kegiatan olahraga yaitu Sepakbola, Futsal, bolabasket yang hanya sebagian siswa yang mengikutinya. Maka tingkat kesegaran jasmani Siswa SMP PGRI Barembeng Kab. Gowa hanya didapatkan dari berolahraga. Berdasarkan permasalahan di atas, maka akan dilaksankan penelitian dengan judul "Survei Sarana dan Prasarana Pendidikan Jasmani dan Tingkat Kesegaran Jasmani Siswa Kelas VIII SMP PGRI Barembeng
Kab. Gowa."

\section{B. Metode Penelitian}

Metode yang dilakukan dalam penelitian ini adalah Survei (Sugiyono, 2015). Dengan menggunakan metode tersebut dapat diperoleh informasi aktual tentang fasilitas sarana dan prasarana olahraga yang terdapat diseluruh SMP PGRI Barembeng. Variabel dalam penelitian ini variabel yang dimaksud adalah Saran dan Prasarana pendidikan jasmani olahraga dan kesehatan. Penelitian ini merupakan jenis penelitian yang bersifat deskriptif yang bertujuan untuk mengetahui kondisi sarana dan prasarana dalam mendukung proses belajar mengajar pendidikan jasmani olahraga dan kesehatan. Penelitian ini di laksanakan di SMP PGRI Barembeng, dengan desain penelitian yang digunakan yakni sebagai berikut.

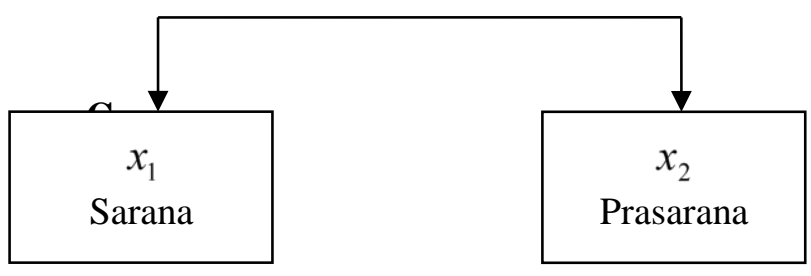

Gambar 1. Desain Penelitian

Populasi dalam penelitian ini adalah seluruh komponen pembelajaran (siswa serta sarana dan prasarana di SMP PGRI Barembeng. Sampel dipilih dengan menggunakan menggunakan teknik purposive random sampling sehingga 
Survei Sarana dan Prasarana Pendidikan Jasmani dan Tingkat Kesegaran Jasmani Siswa Kelas VIII SMP

PGRI Barembeng Kabupaten Gowa

E-ISSN: 2722-3450

diperoleh siswa putra kelas VIII SMP PGRI

Barembeng. Pengumpulan data yang digunakan dalam penelitian ini adalah dengan melalui survei yaitu melakukan pengamatan secara langsung ke obyek penelitian tentang kondisi sarana dan prasarana dalam mendukung proses belajar mengajar pendidikan jasmani dan olahraga dan instrumen tes kesegaran jasmani yang terdiri dari (1) lari cepat 50 meter, (2) tes gantung angkat tubuh 60 detik, (3) tes baring duduk 60 detik, (4) loncat tegak, dan (5) lari 1000 meter. Dalam penelitian ini, penulis menggunakan rancangan statistik deskriptif melalui pendekatan persentase dengan cara mempersentasekan tentang fasilitas dan sarana pendidikan jasmani dan tingkat kesegaran jasmani di SMP PGRI Barembeng, kemudian dibandingkan dengan pedoman penilaian pada setiap komponen yaitu sebagai berikut.

Tabel 1. Presentase dan Kategori Sarana dan prasarana olahraga

\begin{tabular}{lcl}
\hline No & Presentase & Kategori \\
\hline 1 & $81 \%-100 \%$ & Ideal Sekali \\
2 & $61 \%-80 \%$ & Ideal \\
3 & $41 \%-60 \%$ & Cukup ideal \\
4 & $21 \%-40 \%$ & Kurang Ideal \\
5 & $0 \%-20 \%$ & Sangat Kurang \\
& & Sekali \\
\hline
\end{tabular}

Tabel 2. Nilai Tes Kesegaran Jasmani

Indonesia untuk Remaja Umur 13 - 15
Tahun Putera

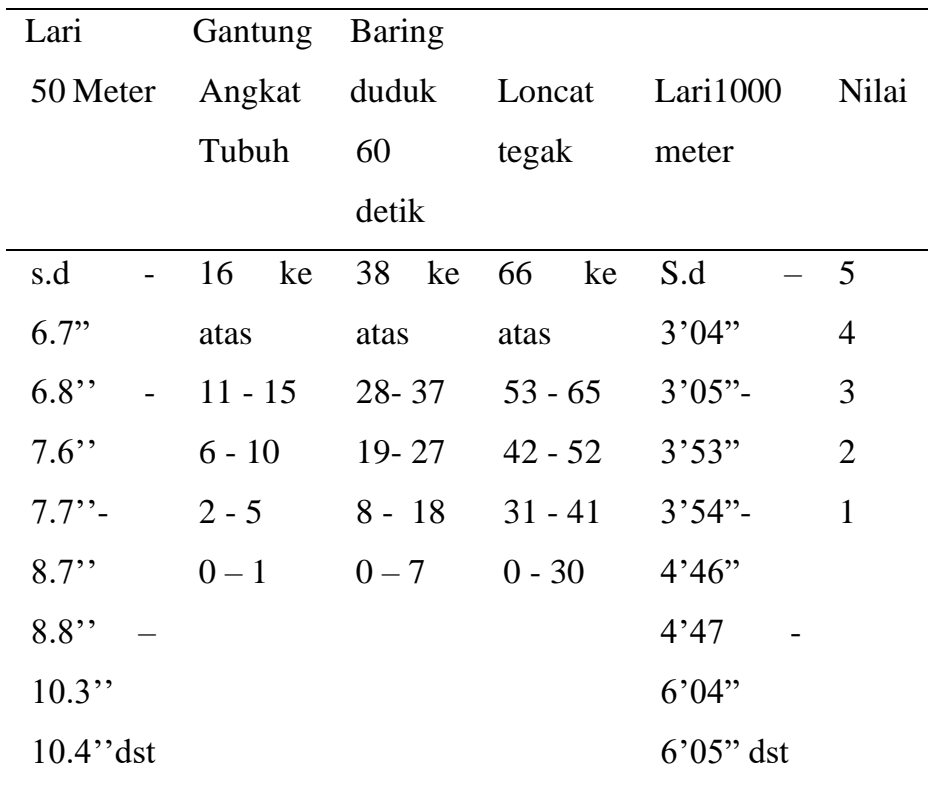

Tabel 3. Norma Tes Kesegaran Jasmani Indonesia Untuk Remaja Umur 13-15 Tahun Putera

\begin{tabular}{lll}
\hline No & $\begin{array}{l}\text { Jumlah } \\
\text { Nilai }\end{array}$ & Klasifikasi \\
\hline 1 & $22-25$ & Baik Sekali \\
2 & $18-21$ & Baik \\
3 & $14-17$ & Sedang \\
4 & $10-13$ & Kurang \\
5 & $5-9$ & Kurang \\
& & sekali \\
\hline
\end{tabular}

\section{Hasil dan Pembahasan}

Berdasarkan hasil observasi dan perhitungan jumlah sarana dan prasarana dari masing-masing cabang olahraga yang ada pada SMP PGRI Barembeng, ditemukan kategori sarana dan prasarana berdasarkan (Arikunto, 2010) sebagai berikut: 


\section{Senam}

Berdasarkan hasil analisis data tentang ketersediaan sarana dan prasarana olahraga senam maka diperoleh hasil seperti terangkum pada tabel berikut.

Tabel 1. Ketersediaan Sarpras Olahraga

Senam pada SMP PGRI Barembeng

\begin{tabular}{llllll}
\hline \multirow{2}{*}{$\mathrm{N}$} & Sarana & dan & \multicolumn{2}{l}{ Frekuensi } & \\
\cline { 3 - 5 } o & Pasarana & & $\begin{array}{l}\text { Stand } \\
\text { ar }\end{array}$ & $\begin{array}{l}\text { Jumla } \\
\text { h }\end{array}$ & \\
& & & & \\
& & 5 & 3 & $60 \%$ \\
\hline 1 & Matras & 1 & 1 & $100 \%$ \\
\hline 2 & Aula & & & \\
\hline Rata-rata & & & & $80 \%$
\end{tabular}

Berdasarkan tabel 1 di atas diketahui bahwa ketersediaan sarana dan prasarana olahraga senam berupa matras 60yang tergolong kategori "cukupIdeal"dan aula,dengan persentase $100 \%$ yang tergolong kategori "Sangat Ideal" dengan rata-rata $80 \%$.

\section{Atletik}

Hasil analisis data tentang ketersediaan sarana dan prasarana olahraga atletik yakni sebagai berikut.

Tabel 2. Ketersediaan Sarpras Olahraga Atletik pada SMP PGRI Barembeng

\begin{tabular}{|c|c|c|c|c|}
\hline \multirow{2}{*}{ No } & \multirow{2}{*}{$\begin{array}{l}\text { Sarana dan } \\
\text { Prasarana }\end{array}$} & \multicolumn{2}{|c|}{ Frekuensi } & \multirow{2}{*}{$\begin{array}{l}\text { Persentase } \\
(\%)\end{array}$} \\
\hline & & Standar & Jumlah & \\
\hline 1. & $\begin{array}{l}\text { Tongkat } \\
\text { estafet }\end{array}$ & 5 & 8 & 100 \\
\hline 2. & Peluru & 5 & 2 & 40 \\
\hline 3. & Lembing & 5 & 4 & 80 \\
\hline 4. & Cakram & 5 & 2 & 40 \\
\hline 5. & Bak lompat & 2 & 1 & 50 \\
\hline 6. & Star Blok & 5 & 8 & 100 \\
\hline 7. & $\begin{array}{l}\text { Tiang } \\
\text { lompat } \\
\text { tinggi }\end{array}$ & 2 & 2 & 100 \\
\hline 8. & $\begin{array}{l}\text { Mistar } \\
\text { lompat } \\
\text { tinggi }\end{array}$ & 2 & 1 & 50 \\
\hline Rata & -rata & & & 70 \\
\hline
\end{tabular}

Berdasarkan tabel 2. diatas diketahui bahwa ketersediaan sarana cabang olahraga atletik berupa tongkat estafet terdapat 100\% dengan kategori “Sangat Ideal”. Sarana cabang olahraga atletik berupa peluru terdapat $40 \%$ dengan kategori "Kurang Ideal". Lembing terdapat $80 \%$ dengankategori“Ideal” Sarana cabang Cakram terdapat $40 \%$ dengan kategori "kurang Ideal"sarana cabang olahraga atletik berupa bak lompat 50\% dengan kategori "cukup Ideal", star blok 100\% dengan kategori "sangat Ideal, tiang lompat tinggi $100 \%$ dengan kategori "sangat Ideal"dan 
Survei Sarana dan Prasarana Pendidikan Jasmani dan Tingkat Kesegaran Jasmani Siswa Kelas VIII SMP

PGRI Barembeng Kabupaten Gowa

E-ISSN: 2722-3450

mistar lompat tinggi terdapat 50\% dengan

kategori “cukup Ideal”. Rata-rata

keseluruhan adalah $70 \%$.

\section{Sepak Bola}

Berdasarkan hasil analisis data tentang ketersediaan sarana dan prasarana olahraga sepak boladiperoleh hasil seperti terangkum pada tabel berikut.

Tabel 3. Ketersediaan Sarpras Olahraga

Sepak Bola pada SMP PGRI Barembeng

\begin{tabular}{lllll}
\hline & Sarana & \multicolumn{2}{l}{ Frekuensi } & Persentase \\
\cline { 2 - 4 } No & dan & Standar & Jumlah & $\begin{array}{l}(\%) \\
\text { Prasarana }\end{array}$ \\
& & & \\
\hline 1. & Bola & 5 & 3 & 60 \\
\hline 2. & Gawang & 2 & 0 & 0 \\
\hline Rata-rata & & & 30
\end{tabular}

Berdasarkan tabel 3. diatas diketahui bahwa ketersediaan sarana dan prasarana olahraga sepak bola berupa gawang dengan persentase $0 \%$ yang tergolong kategori "Sangat kurang Ideal". Adapun sarana berupa

\begin{tabular}{lllll}
\hline & Sarana & \multicolumn{2}{l}{ Frekuensi } & Persentase \\
\cline { 3 - 4 } No & dan & Standa & $\mathrm{Jlh}$ & $(\%)$ \\
& Prasarana & $\mathrm{r}$ & & \\
\hline 1. & Lapangan & 1 & 1 & 100 \\
\hline 2. & Bola & 5 & 2 & 40 \\
\hline 3. & Tiang & 2 & 2 & 100 \\
& ring & & & \\
\hline Rata-rata & & & 80 \\
\hline
\end{tabular}

bola dengan persentase $60 \%$ yang tergolong kategori "cukup Ideal”. Rata-rata keseluruhan adalah $30 \%$.

4. Bola Voli

Berdasarkan hasil analisis data tentang ketersediaan sarana dan prasarana olahraga voli diperoleh hasil seperti terangkum pada tabel berikut.

Tabel 4. Ketersediaan Sarpras Olahraga

BolaVoli pada SMP PGRI Barembeng

\begin{tabular}{lllll}
\hline & Sarana & \multicolumn{2}{l}{ Frekuensi } & Persentase \\
\cline { 3 - 4 } No & dan & Standar & Jumlah & \\
& Prasarana & & & \\
\hline 1. & Lapangan & 1 & 1 & 100 \\
\hline 2. & Bola & 5 & 2 & 40 \\
\hline 3. & Net & 4 & 1 & 100 \\
\hline 4. & Tiang net & 2 & 2 & 100 \\
\hline Rata-rata & & & 85
\end{tabular}

Berdasarkan tabel 4. di atas diketahui bahwa ketersediaan sarana dan prasarana cabang olahraga bola voli berupa lapangan, net, tiang net terdapat $100 \%$, yang tergolong dalam kategori "Sangat Ideal", dan bola 40\% yang tergolong dalam kategori "kurang Ideal". Rata-rata keseluruhan adalah 85\%.

5. Bola Basket

Berdasarkan hasil analisis data tentang ketersediaan sarana dan prasarana olahraga basket diperoleh hasil seperti terangkum pada tabel berikut.

Tabel 5. Ketersediaan Sarpras Olahraga Bola Basket pada SMP PGRI Barembeng

Berdasarkan tabel 5 di atas diketahui bahwa ketersediaan sarana dan prasarana 


\begin{tabular}{ccccc}
\hline \multirow{2}{*}{ No } & $\begin{array}{c}\text { Sarana dan } \\
\text { Prasarana }\end{array}$ & \multicolumn{2}{c}{ Frekuensi } & $\begin{array}{c}\text { Persentase } \\
(\%)\end{array}$ \\
\cline { 3 - 4 } 1. & Lapangan & Standar & Jumlah & 1 \\
\hline 2. & Bola & 5 & 1 & 100 \\
\hline 3. & Net & 1 & 1 & 40 \\
\hline 4. & Tiang Net & 2 & 2 & 100 \\
\hline \multicolumn{4}{c}{ Rata-rata } \\
\hline
\end{tabular}

cabang olahraga Bola Basket berupa Lapangan, tiang ring terdapat 100\%, yang tergolong "Sangat Ideal”, dan bola $40 \%$ yang tergolong dalam kategori "kurang Ideal". Rata-rata keseluruhan $80 \%$.

\section{Bulutangkis}

Berdasarkan hasil analisis data tentang ketersediaan sarana dan prasarana olahraga bulutangkis diperoleh hasil seperti terangkum pada tabel berikut.

Tabel 6. Ketersediaan Sarpras Olahraga Bulutangkis pada SMP PGRI Barembeng

Berdasarkan tabel diatas diketahui bahwa ketersediaan sarana dan prasarana cabang olahraga bulutangkisberupa lapangan, net dan tiang net terdapat $100 \%$. Ini berarti secara umum menunjukkan bahwa ketersediaan sarana dan prasarana cabang olahraga bulutangkis dikategorikan "Sangat Ideal".shuttlecock $83.3 \%$ dikategorikan “ sangat Ideal", raket $60 \%$ dikategorikan "Ideal". Rata-rata keseluruhan $88.66 \%$.

\section{Sepak Takraw}

Berdasarkan hasil analisis data tentang ketersediaan sarana dan prasarana olahraga sepak takraw pada SMP PGRI Barembeng, diperoleh hasil seperti terangkum pada tabel berikut.

Tabel 7. Ketersediaan Sarpras Olahraga Sepak Takraw pada SMP PGRI Barembeng

\begin{tabular}{lllll}
\hline \multirow{2}{*}{ No } & Sarana dan & \multicolumn{2}{l}{ Frekuensi } & Persentase \\
\cline { 3 - 4 } & Prasarana & Standar & Jumlah & $(\%)$ \\
\hline 1. & Lapangan & 1 & 1 & 100 \\
\hline 2. & Bola & 5 & 2 & 40 \\
\hline 3. & Net & 1 & 1 & 100 \\
\hline 4. & Tiang Net & 2 & 2 & 100 \\
\hline Rata-rata & & & 85 \\
\hline
\end{tabular}

Berdasarkan tabel 7. di atas diketahui bahwa ketersediaan sarana dan prasarana cabang olahraga sepak takraw berupa lapangan, net, dan tiang net terdapat $100 \%$ termasuk dalam kategori "Sangat Ideal", bola terdapat $40 \%$ termasuk dalam kategori “kurang Ideal". Rata-rata keseluruhan $85 \%$.

\section{Tenis Meja}

Berdasarkan hasil analisis data tentang ketersediaan sarana dan prasarana olahraga tenismeja pada SMP PGRI Barembeng, diperoleh hasil seperti terangkum pada tabel berikut.

Tabel 8. Ketersediaan Sarpras Olahraga

TenisMeja pada SMP PGRI Barembeng 


\begin{tabular}{lllll}
\hline \multirow{2}{*}{ No } & Sarana dan & \multicolumn{2}{l}{ Frekuensi } & Presentase \\
\cline { 3 - 4 } & Prasarana & Standar & Jumlah & $(\%)$ \\
\hline 1. & Lapangan & 1 & 2 & 100 \\
\hline 2. & Bola & 12 & 12 & 100 \\
\hline 3. & Bad & 5 & 4 & 80 \\
\hline 4. & Net & 1 & 3 & 100 \\
\hline 5. & Tiang Net & 2 & 4 & 100 \\
\hline Rata-rata & & & 96
\end{tabular}

Berdasarkan tabel 8 di atas diketahui bahwa ketersediaan sarana dan prasarana cabang olahraga tenis meja berupa lapangan, net, bola dan tiang net terdapat $100 \%$ dikategorikan "Sangat Ideal”. Sarana cabang olahraga tenis meja berupa bad terdapat $80 \%$ dengan kategori "Sangat Ideal". Rata-rata keseluruhan $96 \%$

\section{Renang}

Renang merupakan cabang olahraga yang membutuhkan fasilitas dengan biaya besar, maka SMP PGRI Barembeng tidak memiliki sarana dan prasarana cabang olahraga renang, sehingga cabang olahraga renang yang merupakan salah satu kompetensi yang harus dianjurkan pada siswa dapat dilaksanakan dengan menggunakan kolam pemerintah daerah.

\section{a. Kondisi Sarana dan Prasarana di SMP PGRI Barembeng}

Hasil penelitian tentang survei sarana dan prasarana menunjukkan bahwa sarana dan prasarana yang dapat ditemukan di SMP
PGRI Barembeng memiliki kategori sarana dan prasarana yang baik. Berdasarkan hasil penelitian dapat disimpulkan bahwa rata-rata sarana dan prasarana pada cabang olahraga senam adalah $80 \%$ dengan kategori "Sangat ideal”, cabang olahraga Atletik 70\% dengan kategori "ideal", cabang olahraga Sepak bola $30 \%$ kategori "kurang ideal”, cabang olahraga Bolavoli 85\% kategori "Sangat ideal", cabang olahraga Bola basket $80 \%$ kategori "ideal", cabang olahraga Bulutangkis 88,66\% dengan kategori "Sangat ideal", cabang olahraga Sepak takraw 85\% kategori "Sangat ideal", dan yang terakhir cabang olahraga Tenis meja 96\% dengan kategori "Sangat ideal".Sehingga dapat ditentukan bahwa rata-rata sarana dan prasarana yang mendukung pembelajaran penjas SMP PGRI Barembeng 76,83\% dengan kategori "ideal".

Kemampuan sekolah dalam pengadaan sarana dan prasarana mata pelajaran pendidikan jasmani relatif terbatas (Arham, 2019). Secara umum sumber pendanaan sekolah adalah dana bantuan operasional sekolah dari pemerintah daerah dan sumbangan orang tua siswa yang jumlahnya terbatas. Pos-pos yang harus dibiayai dari sumber dana tersebut relatif banyak sehingga perlu pemerataan. Perlu diketahui bahwa biaya yang harus dikeluarkan untuk 
pengadaan sarana dan prasana belajar pendidikan jasmani relatif lebih besar dari mata pelajaran lain sehingga dengan keterbatasan dana akan memberatkan sekolah dalam penyediaan sarana dan prasaran pendidikan jasmani tersebut secara lengkap (Wisdiastuti, 2019). Walaupun masih ada beberapa yang mengalami kekurangan dalam pengadaan sarana dan prasarana olahraganya namun hal ini bukan merupakan hambatan bagi sekolah dalam menyelenggarakan pembelajaran Pendidikan Jasmani di sekolahnya masing-masing sebab dengan keterbatasan sarana dan prasarana sekolah tersebut justru menjadi tantangan yang harus diatasi oleh pihak sekolah bersama-sama dengan guru Pendidikan Jasmani guna mencari solusi terbaik untuk permasalahan ini (Arham, 2019).

\section{b. Tingkat Kesegaran Jasmani Siswa Kelas VIII SMP PGRI Barembeng}

Hasil uji hipotesis yaitu tingkat kesegaran jasmani siswa kelas VIII SMP PGRI Barembeng Kab.Gowa termasuk dalam kategori sedang. Apabila hasil penelitian ini dikaitkan dengan teori dan kerangka berpikir yang mendasarinya, maka pada dasarnya hasil penelitian ini mendukung dan memperkuat teori dan hasil-hasil penelitian terdahulu, bahwa tingkat kesegaran jasmani yang baik, dimana hasil penelitian tes tingkat kesegaran jasmani yang diperoleh: Tingkat kesegaran jasmani siswa kelas VIII SMP PGRI Barembeng, diketahui bahwa dari 40 sampel siswa ternyata tidak ada siswa yang memiliki klasifikasi baik sekali, yang memiliki klasifikasikan baik sebanyak 5 siswa (12.5\%), klasifikasi sedang sebanyak 33 siswa (82.5\%), klasifikasi kurang sebanyak 2 siswa (5\%), dan kurang sekali sebanyak 0 siswa (0\%). Dengan demikian, dapat disimpulkan bahwa hasil tes tingkat kesegaran jasmani pada siswa kelas VIII SMP PGRI Barembeng dapat dikategorikan sedang.

Hasil tes kesegaran jasmani siswa kelas VIII SMP PGRI Barembeng kategori sedang, dengan hasil tersebut diduga dipengaruhi beberapa faktor. Adapun faktor-faktor yang mempengaruhi tingkat kesegaran jasmani siswa tersebut antara lain siswa kurang aktifitas jasmani di luar sekolah, makanan dan gizi yang kurang mencukupi, istirahat dan makan yang tidak teratur, kebiasaan hidup dan lingkungan yang kurang sehat (Ardiansyah \& Nasrullah, 2017). Untuk mendapatkan tingkat kesegaran jasmani yang baik, dibutuhkan antara lain makanan dan gizi, tidur dan istirahat, latihan jasmani dan olahraga, kebiasaan hidup sehat serta lingkungan yang sehat (Nurcahyo, 2014). 
Faktor yang paling berpengaruh yang menyebabkan tingkat kesegaran jasmani yang ditemukan oleh peneliti yaitu (Humaedi et al., 2019):

1. Guru Penjas Orkes dalam mengajar tidak memasukkan unsur kegiatan yang menunjang peningkatan kesegaran jasmani siswanya.

2. Di sekolah tidak diprogramkan kegiatan yang menunjang peningkatan kesegaran jasmani, misal senam kesegaran jasmani yang harus dilaksanakan setiap minggunya.

3. Siswa di lingkungan tempat tinggalnya enggan untuk mengikuti kegiatan olahraga.

4. Kurang tersedianya lapangan olahraga dan klub olahraga di lingkungan tempat tinggalnya.

\section{c. Pengaruh Sarana dan Prasarana} Terhadap Tingkat Kesegaran Jasmani Siswa Kelas VIII SMP PGRI Barembeng Kab. Gowa

Berdasarkan tabel uji regresi terlihat nilai Sig. sebesar 0,007. Karena nilai.Sig. $0,007<0,05$, maka dapatdiketahui bahwa sarana dan prasarana mempunyai pengaruh yang signifikan terhadap Tingkat Kesegaran Jasmani dengan koefisien korelasi sebesar
0.423 dan koefisien determinasi sebesar 0.179 artinya sebesar $17.9 \%$ pengaruh sarana dan prasarana terhadap Tingkat Kesegaran Jasmani. Dalam hal ini Tingkat Kesegaran Jasmani seperti diketahui bahwa sarana merupakan peralatan dan perlengkapan yang secara langsung dipergunakan dan menunjang proses Pendidikan . Khususnya proses belajar mengajar yang dilengkapi oleh sarana olahraga sesuai dengan cabang olahraga. Kemampuan seseorang dalam melakukan suatu kegiatan sehari-hari dalam waktu tertentu tanpa mengalami kelelahan yang berarti orang tersebut masih mempunyai cadangan tenaga untuk melakukan suatu kegiatan (Widodo \& Kusnanik, 2013). Seseorang seseorang dengan kesegaran jasmani yang baik, maka tidak akan mengalami gangguan fungsi tubuh dalam melaksanakan pekerjaannya sehingga dapat meningkatkan produktifitas kerja yang baik (Sulistiono, 2014). Jadi untuk mendapatkan tingkat Kesegaran Jasmani yang baik perlu didukung oleh sarana dan prasarana yang baik pula (Jannah \& Sontani, 2018).

Untuk meningkatkan tingkat Kesegaran Jasmani yang maksimal, tentunya diperhatikan berbagai faktor yang membangkitkan para siswa untuk berlatih dengan efektif (Sepriadi, 2017). Hal tersebut

http://ejurnal.ubharajaya.ac.id/index.php/JCESPORTS 
dapat ditingkatkan apabila ada sarana yang penunjang, yaitu faktor sarana dan prasarana dan dapat memanfaatkan dengan tepat dan seoptimal mungkin pasti akan memberikan dampak yang positif terhadap hasil belajarnya (Miski, 2015). Walaupun masih ada beberapa kekurangan dalam pengadaan sarana dan prasarana pendidikan jasmani olahraga dan kesehatan, namun hal ini bukan merupakan hambatan bagi sekolah dalam menyelenggarakan pembelajaran pendidikan jasmani olahraga dan kesehatan disekolahnya, sebab keterbatasan sarana dan prasarana pendidikan jasmani olahraga dan kesehatan yang mampu disediakan sekolah tersebut, justru menjadi tantangan yang harus diatasi oleh pihak sekolah bersama-sama dengan guru pendidikan jasmani olahraga dan kesehatan, guna mencari solusi terbaik (Wisdiastuti, 2019).

\section{Kesimpulan}

Berdasarkan hasil penelitian dan pembahasannya, maka dapat diambil suatu simpulan sebagai berikut: a) Kondisi sarana dan prasarana yang mendukung pembelajaran penjas SMP PGRI Barembeng dikategorikan ideal. b) Tingkat kesegaran jasmani kelas VIII SMP PGRI Barembeng dapat dikategorikan sedang. c) Ada pengaruh sarana dan prasarana terhadap
Tingkat Kesegaran Jasmani SMP PGRI Barembeng

Berdasarkan kesimpulan di atas terdapat beberapa hal yang dapat direkomendasikan, yaitu antara lain: Kepada para guru agar kiranya pengajaran penjas haruslah disesuaikan dengan kurikulum dan sarana dan prasarana dalam pencapaian tingkat kesegaran jasmani siswa secara maksimal, terus memberikan informasi tentang bagaimana memelihara kesegaran tubuh dan kesehatan diri dan lingkungan dengan baik.; Bagi guru pendidikan jasmani dan siswa diharapkan dapat memahami pentingnya menjaga dan meningkatkan tingkat kesegaran jasmani dalam mendukung aktifitas dalam kegiatannya sehari-hari dengan rutin melakukan olahraga; Diharapkan pada penelitian yang akan datang, khususnya penelitian yang relevan dengan penelitian ini disarankan melibatkan lebih banyak lagi teknik dasar lainnya dan menggunakan sampel yang lebih besar agar hasil yang dicapai lebih sempurna lagi

\section{Daftar pustaka}

Alif, M. N., \& Sudirjo, E. (2019). Filsafat Pendidikan Jasmani. UPI Sumedang Press.

https://books.google.co.id/books?id=or HNDwAAQBAJ\&lpg=PR1\&ots=z_W 
Survei Sarana dan Prasarana Pendidikan Jasmani dan Tingkat Kesegaran Jasmani Siswa Kelas VIII SMP PGRI Barembeng Kabupaten Gowa

$48 \mathrm{WydFJ} \& \mathrm{dq}=$ pendidikan

jasmani\&lr\&hl=id\&pg=PP3\#v=onepag

$\mathrm{e} \& \mathrm{q}=$ pendidikan jasmani $\& \mathrm{f}=$ false

Ardiansyah, M., \& Nasrullah, N. (2017).

Analisis Tingkat Daya Tahan

Kardiorespirasi Wasit Sepakbola Di

Palembang Tahun 2017. Jurnal

Prestasi, $\quad$ 1(2), 35-40.

https://doi.org/https://doi.org/10.24114/

jp.v1i2.8064

Arham, S. (2019). Ketersediaan Sarana dan Prasarana Terhadap Pelaksanaan Pembelajaran Pendidikan Jasmani di SMA Negeri 3 Makassar. Celebes Education Review, 1(2), 53-58. https://doi.org/https://doi.org/10.37541/ cer.v1i1.256

Arikunto, S. (2010). Prosedur Penelitian Suatu Pendekatan Praktik (edisi revisi 2010). In Jakarta: Rineka Cipta (10th ed.).

Herlina, H., \& Suherman, M. (2020). Potensi Pembelajaran Pendidikan Jasmani Olahraga Dan Kesehatan (Pjok) Di Tengah Pandemi Corona Virus Disease (Covid)-19 Di Sekolah Dasar. Tadulako Journal Sport Sciences And Physical Education, $\quad 8(1), \quad 1-7$. http://jurnal.untad.ac.id/jurnal/index.ph p/PJKR/article/view/16186

Humaedi, Iskandar, H., \& Abduh, I. (2019).
Pengembangan Model Pembelajaran Outbound padaPendidikan Jasmani dalam Meningkatkan Kesegaran Jasmani Siswa. Jurnal Inspirasi Pendidikan, $\quad 9(2), \quad$ 117-122. https://doi.org/https://doi.org/10.21067/ jip.v9i2.3325

Irawan, R. (2017). Studi Kelayakan Fasilitas Sarpras Olahraga Indoor di FIK Unnes. Jurnal Penjakora, 4(1), 90-102. https://doi.org/http://dx.doi.org/10.2388 7/penjakora.v4i1.11756

Jannah, S. N., \& Sontani, U. T. (2018). Sarana dan prasarana pembelajaran sebagai faktor determinan terhadap motivasi belajar siswa ( Learning facilities and infrastructure as a factor determinant to student learning motivation ). Jurnal Manajemen Pendidikan Perkantoran, 3(1), 63-70. https://doi.org/10.17509/jpm.v3i1.9457 Lengkana, A. S., Sofa, N. S. N., \& Artikel, I. (2017). Kebijakan Pendidikan Jasmani dalam Pendidikan. Jurnal Olahraga, $3(1)$, $1-12$ https://doi.org/https://doi.org/10.37742/ jo.v3i1.67

Miski, R. (2015). Pengaruh Sarana dan Prasarana terhadap Hasil Belajar. Jurnal Tadbir Muwahhid, 4(2), 17-21. https://doi.org/http://dx.doi.org/10.3099 
7/jtm.v4i2.341

Nurcahyo, E. (2014). Survei Tingkat Kesegaran Jasmani Siswa Kelas Xi (Sebelas) Sma Muhammadiyah 1 Babat Kabupaten Lamongan. Jurnal Pendidikan Olahraga Dan Kesehatan, 2(1), 88-93. https://jurnalmahasiswa.unesa.ac.id/ind ex.php/jurnal-pendidikanjasmani/article/view/8041

Pasaribu, A. M. N., \& Daulay, D. E. (2018). PENGARUH PERMAINAN LARI ESTAFET TERHADAP KEMAMPUAN GERAK DASAR MOTORIK KASAR SISWA KELAS 3 SDN KARET II KABUPATEN TANGERANG. Prestasi, 2(4), 9-14. https://doi.org/https://doi.org/10.24114/ jp.v2i4.11909

Pasaribu, A. M. N., \& Mashuri, H. (2019). The role of rhythmic gymnastics for physical fitness for elementary school students. Jurnal SPORTIF: Jurnal Penelitian Pembelajaran, 5(1 SEArticle), 89-97. https://doi.org/10.29407/js_unpgri.v5i1. 12551

Pratama, A. C., \& Tjahyo, B. F. (2018). Survei Sarana Prasarana Pendidikan Jasmani Olahraga Dan Kesehatan, Sekolah Menengah Pertama Dan
Sederajat. $\quad 6(3), \quad 561-564$. https://jurnalmahasiswa.unesa.ac.id/ind ex.php/jurnal-pendidikanjasmani/article/view/25229

Sepriadi. (2017). Kontribusi Status Gizi dan Kemampuan Motorik terhadap Kesegaran Jasmani Siswa Sekolah Dasar. Jurnal Keolahragaan, 5(2), 194206.

https://doi.org/https://doi.org/10.21831/ jk.v5i2.15147

Sugiyono, P. D. (2015). Metode Penelitian dan Pengembangan. Res. Dev. D.

Sulistiono, A. A. (2014). Kebugaran Jasmani Siswa Pendidikan Dasar dan Menengah di Jawa Barat. Jurnal Pendidikan Dan Kebudayaan, 20(2), 223-233.

Widodo, B. S., \& Kusnanik, N. W. (2013). Tingkat Kesegaran Jasmani Pada Siswa SMP Negeri 2 Krembung Dan SMP Negeri 2 Sidoarjo. Jurnal Prestasi Olahraga, $\quad 1(1), \quad 1-5$. https://jurnalmahasiswa.unesa.ac.id/ind ex.php/jurnal-prestasi-

olahraga/article/view/2146/1317

Wijaya, F. (2017). Ketersediaan Sarana Dan Prasarana Pembelajaran Pendidikan Jasmani, Olahraga Dan Kesehatan Di Sma Negeri Kabupaten Sumenep. 5(2), 232-235. https://jurnalmahasiswa.unesa.ac.id/ind 
ex.php/jurnal-pendidikan-

jasmani/article/view/21247

Wisdiastuti, W. (2019). Mengatasi

Keterbatasan Sarana Prasarana Pada

Pembelajaran Pendidikan Jasmani

[Overcoming Facilities Limitations

Affecting Physical Education Learning

Activities]. Polygot: Jurnal Ilmiah,

15(1), 140-155.

https://doi.org/http://dx.doi.org/10.1916

6/pji.v15i1.1091 